\section{Fracture strength of teeth restored with milled ultrathin occlusal veneers made of polymer-infiltrated ceramic}

Laerte Ohse1, Deborah Stona1, Marília M. Sly (D2, Luiz Henrique Burnett Júnior (D)1, Ana Maria Spohr (D).

\begin{abstract}
The purpose was to evaluate, in vitro, the fracture strength of teeth restored with 0.3 - or 0.6-mm-thick occlusal veneers made of Vita Enamic ${ }^{\circledR}$ bonded to enamel or dentin. Fifty third molars were allocated into five groups $(n=10)$ : Group C - control (sound teeth); Group 0.3E - 0.3-mm-thick occlusal veneers bonded to enamel; Group 0.6E - 0.6-mm-thick occlusal veneers bonded to enamel; Group 0.3D - 0.3-mm-thick occlusal veneers bonded to dentin; Group $0.6 \mathrm{D}-0.6-\mathrm{mm}$-thick occlusal veneers bonded to dentin. After luting with Single Bond Universal and Filtek Z-100, the samples were subjected to fracture strength test in a universal testing machine. The fractures were classified as irreparable and reparable. Data were analyzed with 2-way and 1-way ANOVA $(\alpha=.05)$ followed by Tukey's test. The teeth restored with $0.3-\mathrm{mm}$-thick occlusal veneers $(2658 \mathrm{~N})$ achieved significantly higher fracture strength compared to the teeth restored with $0.6-\mathrm{mm}$-thick occlusal veneers $(2070 \mathrm{~N})$ $(p=0.017)$. The teeth restored with occlusal veneers bonded to enamel (2648 $\mathrm{N})$ had significantly higher fracture strength compared to the teeth restored with occlusal veneers bonded to dentin $(2049 \mathrm{~N})(\mathrm{p}=0.015)$. Group C $(3355 \mathrm{~N})$ and Group 0.3E $(2965 \mathrm{~N})$ did not differ significantly from each other, being the fracture strength significantly higher than the other groups $(p<0.05)$. The fractures were predominantly reparable. The teeth restored with $0.3-\mathrm{mm}$-thick occlusal veneers achieved higher fracture strength compared to the teeth restored with $0.6-\mathrm{mm}$-thick occlusal veneers. The supporting substrate influenced the fracture strength, which was higher for the teeth restored with occlusal veneers bonded to enamel.
\end{abstract}

\begin{abstract}
1 Department of Restorative Dentistry, Pontifícia Universidade Católica do Rio Grande do Sul PUC-RS, Porto Alegre, RS, Brazil.
\end{abstract}

${ }^{2}$ Restorative Dentistry and Prosthodontics, Universtity of Texas, UTHealth Houston School of Dentistry, Texas, Houston, USA.

Correspondence: Ana Maria Spohr; School of Dentistry - Pontifical Catholic University of Rio Grande do Sul; Avenida Ipiranga, 6681; 90619900 Porto Alegre, RS, Brazil; Phone/fax.: +5551-3320.3538

E-mail address: ana.spohr@pucrs.br

Key Words: Dentin; Dental enamel; Ceramics

\title{
Introduction
}

The continuous reduction of tooth enamel occurs with advancing age. However, there are events that can cause early loss of this tissue, such as erosion due to gastroesophageal reflux, high consumption of acidic foods and beverages, medications, and nervous bulimia. In addition, bruxism is a common parafunctional habit, and one of the possible sequelae is tooth wear (1). Regardless of the origin, severe wear of dental tissue causes aesthetic and functional problems (2).

Ultrathin occlusal veneers have been used to restore the occlusal vertical dimension (OVD) as well as the aesthetic with minimally invasive preparations that allow greater preservation of the dental structure and maintenance of pulp vitality $(3,4)$. Different materials are available for computer-aided design/computer-aided manufacturing (CAD/CAM) technology, which has been used more frequently in the manufacture of ultrathin restorations in the last 10 years (5).

Among the different materials, lithium disilicate ceramic for the manufacture of ultrathin occlusal veneers has been shown to be a conservative choice to traditional inlays, onlays and full crowns, demonstrating promising results $(3,4,6)$. Nanoceramic composite represents another alternative for ultrathin occlusal veneers, showing superior results for fatigue resistance in relation to lithium disilicate ceramic $(3,4)$. Another material, called hybrid ceramic, consists of a polymer-infiltrated ceramic network material (PICN). This material has two different components: a network of sintered ceramic infiltrated by a resin matrix. The aim of this new material is to allow ultrathin restorations $(0.2-0.5-\mathrm{mm})$, faster milling without cracks in the ceramic blocks, and good mechanical behavior after luting (7).

Few studies have evaluated the fracture strength of ultrathin occlusal veneers made of PICN bonded to enamel $(8,9)$ or bonded to dentin $(6,10)$. Regarding fracture, different minimal occlusal thicknesses were evaluated, including $0.5 \mathrm{~mm}(9,11), 0.5 \mathrm{~mm}$ or $1.0 \mathrm{~mm}(8,10)$, and $0.6 \mathrm{~mm}$ or $1.5 \mathrm{~mm}$ 
(6). The studies concluded that ultrathin occlusal veneers made of PICN are suitable for use in the posterior region $(6,8,10)$. In addition, the concepts of minimally invasive cosmetic dentistry and minimally invasive prosthetic procedure have been rising with time, demanding restorations with very low thicknesses (12). However, it would be interesting to evaluate thinner occlusal veneers, such as $0.3-\mathrm{mm}-$ thick veneers, since the material has this indication (13).

There are different degrees of dental erosion. The mineral loss may be only on the enamel, or it may progress and expose the dentin $(1,2)$. Therefore, restorations are bonded to enamel and/or dentin, and the supporting substrate may affect the fracture strength of the restorations (14). According to Facenda et al. (14) substrates with greater elastic modulus promoted greater fracture strength values of PICN. Therefore, the literature lacks studies assessing, under the same methodology, the fracture strength of thinner occlusal veneers made of PICN, such as $0.3-\mathrm{mm}$-thick veneers bonded to enamel or dentin substrates. The purpose of this laboratory study was to evaluate the fracture strength of teeth restored with 0.3- or 0.6-mm-thick occlusal veneers made of PICN bonded to enamel or dentin. The hypotheses of the study were that (i) the thickness of the occlusal veneers and (ii) the substrate influence the fracture strength of the teeth restored with ultrathin occlusal veneers.

\section{Material and Methods}

Tooth selection

The Ethics Committee (55675416.7.0000.5336) approved the study protocol. Fifty human third molars, extracted for therapeutic reasons and free of restorations, caries, cracks or fractures, were selected after measurement of the mesiodistal $(\cong 10.5 \mathrm{~mm})$ and buccal-lingual $(\cong 9.5 \mathrm{~mm})$ dimensions with a digital caliper (500-197-20 Mitutoyo, Kawasaki, Japan). A 0.5-mm variation for each measurement was accepted with the objective to standardize the dimensions of the teeth. The teeth were cleaned, disinfected in $0.5 \%$ chloramine T solution for $24 \mathrm{~h}$, stored in distilled water at $4^{\circ} \mathrm{C}$, and used within 4 months. The teeth were randomly allocated into five different groups $(n=10)$ : Group $C-$ control (sound teeth); Group 0.3E - 0.3-mm-thick occlusal veneers made of Vita Enamic ${ }^{\varpi}$ (VITA Zahnfabrik, Bad Säckingen, Germany) bonded to enamel; Group 0.6E - 0.6-mm-thick occlusal veneers bonded to enamel; Group 0.3D - 0.3-mm-thick occlusal veneers bonded to dentin; and Group 0.6D 0.6-mm-thick occlusal veneers bonded to dentin. One trained operator performed all experimental steps.

\section{Periodontal ligament simulation}

The periodontal ligament was artificially created with vinyl polysiloxane. The root portion was covered by a layer of adhesive (Universal Tray Adhesive, Zhermack, Rovigo, Italy) and left to dry. Subsequently, a thin layer of regular viscosity vinyl polysiloxane (Express Standard - 3M, St. Paul, MN, USA) was applied over the adhesive with a brush.

\section{Tooth preparation}

The roots of each tooth were mounted vertically in a plastic cylinder with self-cured acrylic resin up to $2 \mathrm{~mm}$ from the enamel-cement junction (ECJ). After polymerization of the acrylic resin, the samples were immersed in distilled water at $4^{\circ} \mathrm{C}$. The preparations were standardized. a) Preparation on enamel: The depth of the preparation was made on enamel using the half active tip of a 2135 diamond bur (KG Sorensen, Cotia, SP, Brazil) at high speed under air-water spray. The finish of the preparation was performed with diamond burs 2135F and 2135FF (KG Sorensen, Cotia, SP, Brazil). The cusps inclination was maintained (Figure 1).

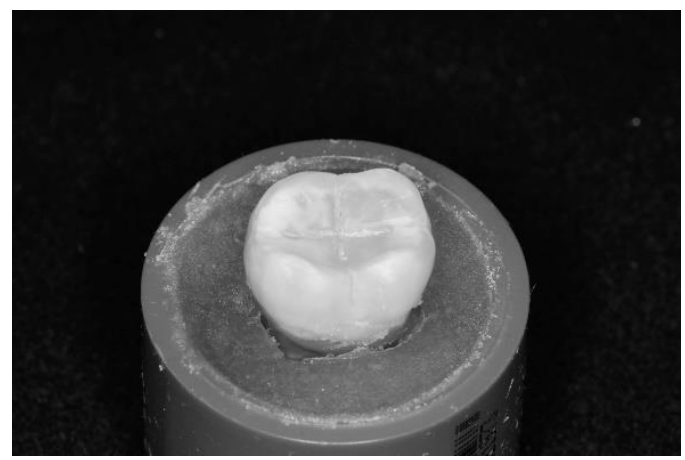

Figure 1: Preparation of the tooth on enamel. 
Preparation on dentin: The exposure of occlusal dentin was performed with a 4138 diamond bur (KG Sorensen, Cotia, SP, Brazil) operating at high speed under air-water spray. The buccal and lingual margins were approximately 2.4 to $2.7 \mathrm{~mm}$ above the central groove and $5 \mathrm{~mm}$ from the ECJ. The cusps inclination was maintained (Figure 2). The finish of the preparation was performed with diamond burs 4138F and 4138FF (KG Sorensen, Cotia, SP, Brazil).

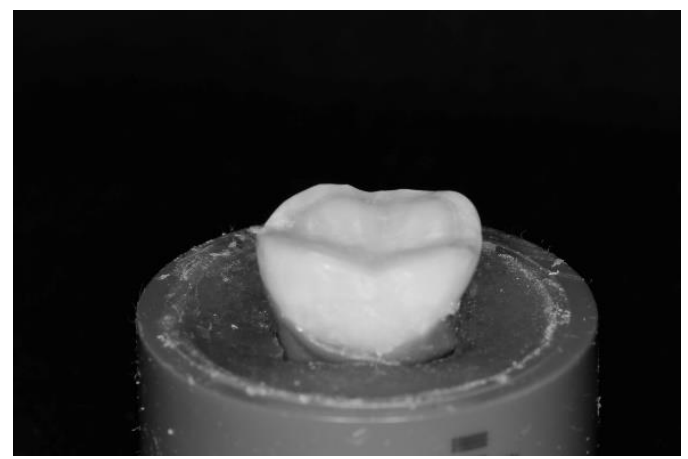

Figure 2: Preparation of the tooth on dentin.

\section{Manufacturing the restorations}

First, reflective titanium (VITA Zahnfabrik, Bad Säckingen, Germany) was applied on the tooth preparation, which was scanned with an optical 3D intraoral camera (Cerec software, version 4.1, Sirona Dental Systems $\mathrm{GmbH}$, Bensheim, Germany). A three-dimensional virtual image was created, and the $\mathrm{CAD} / \mathrm{CAM}$ occlusal veneers were shaped according to the occlusal anatomy of a right second lower molar. The thicknesses of $0.3-$ or $0.6-\mathrm{mm}$ occlusal veneers were defined by the software, and the virtual die spacer was set at $50 \mu \mathrm{m}$. Forty occlusal veneers made of a polymer-infiltrated ceramic network (PICN Vita Enamic ${ }^{\oplus}$, VITA, Zahnfabrik, Germany) were fabricated in the milling unit inLab MC XL (Dentsply Sirona, Charlotte, NC, USA): twenty 0.3-mm-thick occlusal veneers and twenty $0.6-\mathrm{mm}$-thick occlusal veneers were fabricated. The occlusal veneers were checked and fitted to the prepared teeth and then polished with a specific Vita Enamic clinical polish kit (VITA, Zahnfabrik, Germany).

\section{Bonding procedure}

The inner surface of the occlusal veneers was etched with 5\% hydrofluoric acid (Condac Porcelain - FGM, Joinville, SC, Brazil) for $60 \mathrm{~s}$, then rinsed off with forceful water spray for $30 \mathrm{~s}$. The silane Scotchbond Ceramic Primer (3M/ESPE, St. Paul MN, USA) was applied and dried gently for $5 \mathrm{~s}$. On the tooth preparation, phosphoric acid at 37\% (Condac - FGM, Joinville, SC, Brazil) was applied on enamel for $30 \mathrm{~s}$ and on dentin for $15 \mathrm{~s}$, rinsed for $30 \mathrm{~s}$ and dried with cotton buds. The adhesive system Single Bond Universal (3M/ESPE, St. Paul MN, USA) was applied to both fitting surfaces of the occlusal veneer and the tooth, and dried gently for $5 \mathrm{~s}$. The resin composite Filtek Z-100 (3M/ESPE, St. Paul MN, USA), preheated to $69^{\circ} \mathrm{C}$ (HotSet - Technolife), was applied to the inner surface of the occlusal veneer. Immediately, the occlusal veneer was positioned on the preparation, followed by the application of a 1$\mathrm{kg}$ load. The excess of preheated resin composite was removed, and each face of the occlusal veneer was light-cured for $20 \mathrm{~s}$ with an LED light unit (VALO, Ultradent, South Jordan, UT, USA) with a light intensity of $1,000 \mathrm{~mW} / \mathrm{cm}^{2}$. The light intensity was monitored with an LED radiometer (SDI, Bayswater, Vic, Australia). The samples were kept in distilled water at $37^{\circ} \mathrm{C}$ for $24 \mathrm{~h}$.

\section{Fracture strength testing}

After storage, the samples were submitted to a fracture strength test using a DL-2000 universal testing machine (EMIC, São José dos Pinhais, PR, Brazil) with a 10-kN cell load. A 6-mm-diameter metal sphere, connected to the load cell, was positioned on the occlusal surface of the veneers to achieve tripodization of contacts along the cuspal inclines over the central fossa. The compression load was applied at a crosshead speed of $1.0 \mathrm{~mm} / \mathrm{min}$ until failure. The values of maximum force were recorded in Newtons (N).

\section{Fracture mode analysis}

After visual examination, the fractures were classified as follows: a) reparable (fracture at the occlusal veneer only, or fracture that involved one or more cusps); or b) irreparable (fracture divided the tooth into two parts at the level of the pulp chamber floor). 


\section{Statistical analysis}

SPSS 10.0 software (SPSS Inc., Chicago, IL, USA) was used for the statistical analysis. The Kolmogorov-Smirnov test showed data normality. The fracture strength values of the experimental groups were evaluated by two-way analysis of variance (ANOVA) (occlusal veneer thickness $x$ substrate) and the Tukey post hoc test. One-way ANOVA and the Tukey post hoc test were used to evaluate the fracture strength values of sound teeth with those of the experimental groups (significance level 0.05 ).

\section{Results}

Two-way ANOVA demonstrated that the thickness $(p=0.005)$ and substrate $(p=0.004)$ had significant effects on the fracture strength. The interaction of these factors $(p=0.742)$ was not significant.

Regardless of the substrate, the teeth restored with $0.3-\mathrm{mm}$-thick occlusal veneers $(2658 \mathrm{~N})$ showed significantly higher fracture strength than the teeth restored with 0.6-mm-thick occlusal veneers $(2070 \mathrm{~N})$ (Table 1).

Table 1. Fracture strength mean $(\mathrm{N})$ between occlusal veneer thicknesses.

\begin{tabular}{cccc}
\hline Thickness & Fracture strength mean $(N)$ & Standard deviation & $\begin{array}{c}\text { Sig } \\
(F ; 1-\beta)\end{array}$ \\
\hline $0.3 \mathrm{~mm}$ & 2658 & 713 & $0.017^{*}$ \\
$0.6 \mathrm{~mm}$ & 2070 & 600 & \\
\hline$*$ * & & $6.107 ; 0.324)$ \\
\hline
\end{tabular}

${ }^{*} P$-value $<0.05$

Regardless of the thickness, the teeth restored with occlusal veneers bonded to enamel (2648 N) showed significantly higher fracture strength than the teeth restored with occlusal veneers bonded to dentin (2049 N) (Table 2).

Table 2. Fracture strength mean $(\mathrm{N})$ between substrates.

\begin{tabular}{cccc}
\hline Substrate & Fracture strength mean $(\mathrm{N})$ & Standard deviation & $\begin{array}{c}\text { Sig } \\
(F ; 1-\beta)\end{array}$ \\
\hline Enamel & 2648 & 660 & $0.015^{*}$ \\
Dentin & 2049 & 650 & $(6.444 ; 0.301)$ \\
\hline
\end{tabular}

${ }^{*} P$-value $<0.05$

According to one-way ANOVA, there was no significant difference between Group C (3355 N) and Group 0.3E $(2965 \mathrm{~N})$, with fracture strengths that were significantly higher than those of the other groups. Group 0.6E (2331 N), Group 0.3D (2315 N) and Group 0.6D (1808 N) did not differ significantly from each other (Table 3).

Table 3. Fracture strength mean $(\mathrm{N})$ and standard deviation in the different groups.

\begin{tabular}{|c|c|c|c|}
\hline Group & $\begin{array}{l}\text { Fracture strength mean } \\
\text { (N) }\end{array}$ & Standard deviation & $\begin{array}{c}\text { Sig } \\
(F ; 1-\beta)\end{array}$ \\
\hline Group C - Control - sound teeth & $3355^{\mathrm{a}}$ & 1064 & $\begin{array}{c}0.0001^{*} \\
(7.073 ; 0.01)\end{array}$ \\
\hline Group 0.3E - $0.3 \mathrm{~mm}$ - enamel & $2965^{\mathrm{a}}$ & 703 & \\
\hline Group 0.6E - $0.6 \mathrm{~mm}$ - enamel & $2331^{b}$ & 448 & \\
\hline Group $0.3 \mathrm{D}-0.3 \mathrm{~mm}-$ dentin & $2315^{b}$ & 580 & \\
\hline Group 0.6D - $0.6 \mathrm{~mm}$ - dentin & $1808^{b}$ & 639 & \\
\hline
\end{tabular}

There was a predominance of reparable fractures in all groups (Table 4). Regarding reparable fractures, there were fractures restricted to restoration only in Group 0.6E (Figure 3). There was predominance of fractures in one or more cusps in Group C, Group 0.3E, Group 0.3D, and Group 0.6D (Figure 4). Irreparable fractures occurred in a few specimens in all groups (Figure 5) (Table 4). 


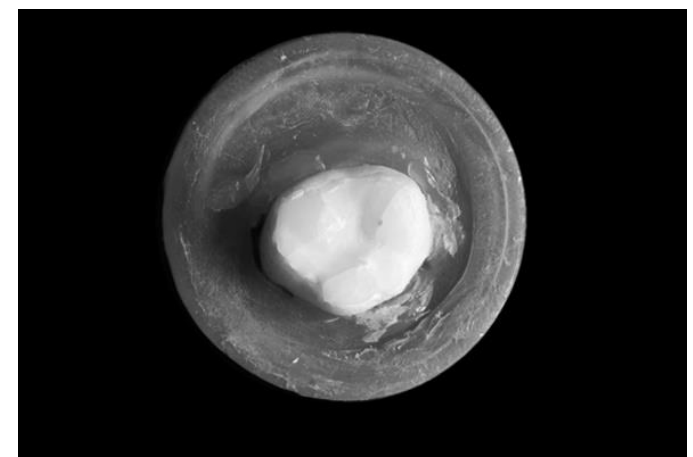

Figure 3. Occlusal veneer fracture (classified as reparable).

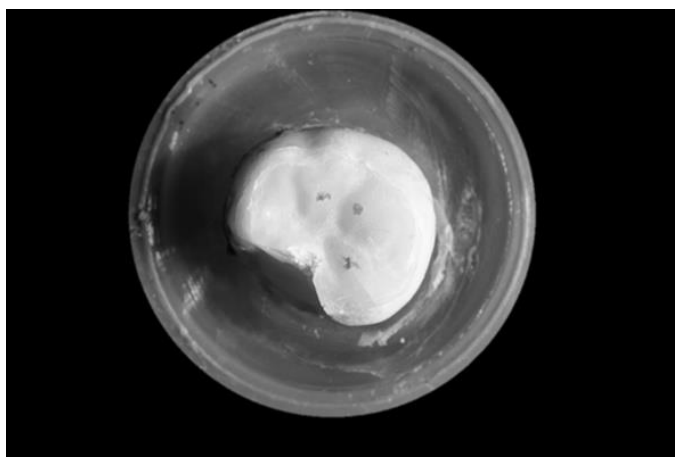

Figure 4. Cusp fracture (classified as reparable).

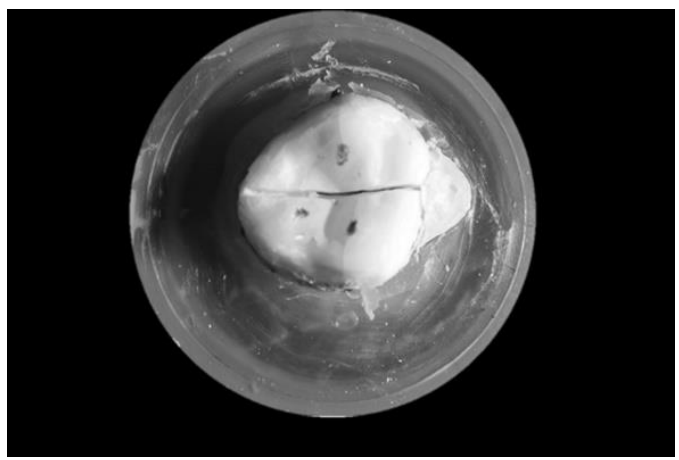

Figure 5. Longitudinal fracture of the tooth into two parts at the pulpal chamber floor (classified as irreparable).

Table 4. Failure analyses of the different groups.

\begin{tabular}{cccc}
\hline & \multicolumn{2}{c}{ Reparable fracture } & Irreparable fracture \\
\cline { 2 - 3 } & $\begin{array}{c}\text { Fracture in the venner } \\
\text { only }\end{array}$ & $\begin{array}{c}\text { Fracture in one or more } \\
\text { cusps }\end{array}$ & \\
\hline Group C - Control - sound teeth & 0 & 7 & 3 \\
Group 0.3E - 0.3 mm - enamel & 0 & 8 & 2 \\
Group 0.6E - $0.6 \mathrm{~mm}$ - enamel & 5 & 4 & 1 \\
Group 0.3D - $0.3 \mathrm{~mm}$ - dentin & 0 & 7 & 3 \\
Group 0.6D - $0.6 \mathrm{~mm}$ - dentin & 0 & 8 & 2 \\
\hline
\end{tabular}

\section{Discussion}

In the present study, higher fracture strength was achieved for the teeth restored with 0.3-mmthick occlusal veneers made of PICN compared to the teeth restored with $0.6-\mathrm{mm}$-thick occlusal veneers, regardless of whether they were bonded to enamel or dentin. This result showed that even under a constant compressive load, an ultrathin occlusal veneer, such as $0.3 \mathrm{~mm}$ thick, achieved high strength. 
Therefore, the first hypothesis was accepted. Studies have shown higher fracture strength for $1.0-\mathrm{mm}-$ thick compared to $0.5-\mathrm{mm}$-thick occlusal veneers (10) and higher fracture strength for 1.5-mm-thick compared to 0.6-mm-thick (6) occlusal veneers made of PICN. However, in the present study, thicker PICN occlusal veneer did not contribute to higher fracture strength values when comparing 0.3- and 0.6 -mm-thick restorations. This result may be related to the possibility of milling PICN material to thin restorations that are still strong enough to avoid cracks, which are stopped by the interpenetrating polymer within the ceramic network (7). This combination of materials aims to increase the mechanical properties, such as strain at failure and flexural strength (15). Possibly, in very low thicknesses such as those used in the present study, the intrinsic strength of the material at 0.6-mm-thick has not been decisive to obtain higher fracture strength in comparison to $0.3-\mathrm{mm}$-thick. Another possible explanation for the higher fracture strength of 0.3-mm-thick occlusal veneers is the bonding protocol.

The bonding protocol of the PICN occlusal veneers was standardized. The Single Bond Universal adhesive system was applied on enamel and dentin in the etch-and-rinse technique. The study of AlAkhali et al. (9) demonstrated that the self-etch technique on enamel decreased the survival rate of Vita Enamic ${ }^{\varpi}$ ultrathin occlusal veneers. Hydrofluoric acid at 5\% was applied on the inner surface of the occlusal veneers for $60 \mathrm{~s}$, followed by the silane. Silane promotes chemical bonding between the silicon contained in the materials and the adhesive material used for bonding (16). Although Single Bond Universal has silane in its composition, studies have shown that the application of silane as a separate step provides greater values of bond strength, independent of the presence of silane within the universal adhesive solution (17).

Following the bonding protocol, a light-curing resin composite was used to bond the occlusal veneers to the tooth preparation. This material was heated, allowing greater flow during the luting procedure. The advantage of using a light-curing resin composite is the extended time to place the restorations in comparison to a dual-cure material. This extended time compensates for the adversity of positioning the restorations because of the lack of an insertion path (3). In addition, resin composite may perform better than resin cement on restoration margins due to more inorganic load filling (18). Regarding photopolymerization, an important factor related to the results of the present study can be the thickness of the ceramic that influenced the light transmittance and degree of conversion of the resinous materials (19). Then, it cannot be ruled out the possibility that the $0.3-\mathrm{mm}$-thick occlusal veneers have contributed to a lower attenuation of the transmitted light in comparison with the 0.6$\mathrm{mm}$-thick occlusal veneers. The possible higher degree of conversion obtained for the teeth restored with 0.3-mm-thick occlusal veneers may have contributed to higher mechanical properties of the Single Bond Universal and Filtek Z-100, promoting higher fracture strength.

A single unit between the tooth and occlusal veneer is obtained with the adhesive luting. Consequently, the forces applied on the restoration bonded to the tooth are dissipated through the tooth structure, periodontal ligament and alveolar bone, preventing concentration of the forces in the inner portion of the restoration, which would lead to fracture (20). The fracture types observed in the study corroborate this finding. Most of the reparable fractures occurred in one or more cusps, and there were few irreparable fractures, showing that load dissipated through the tooth. Only in Group 0.6E occurred fractures restricted to the occlusal veneer, without any damage to the tooth substrate. Therefore, the thicker occlusal veneers bonded to enamel transmitted fewer forces to the substrate, concentrating the stresses in the internal part of the restoration.

Vita Enamic is a brand of PICN. This material associates the properties of ceramic and polymer as a hybrid structure with two interpenetrating networks of ceramic (86 wt $\%$ ) and polymer (14 wt\%) (7). Vita Enamic ${ }^{\circledR}$ presents a flexural strength of $131 \mathrm{MPa}$ and an elastic modulus of $26.3 \mathrm{GPa}$ (21), which is close to that of dentin (18.3 GPa) (22). In addition, Vickers hardness of this material lies between enamel and dentin (7). Ceramics with lower elastic modulus, closer to that of dentin, can better resist loads and better avoid crack propagation (15). In this study, the occlusal veneers were bonded to preparations on enamel only or were bonded to preparations on dentin with enamel margins. The enamel elastic modulus $(84 \mathrm{GPa})$ is greater than the dentin elastic modulus (18.3 GPa) (22). The study of Piemjai et al. (23) showed that the fracture strength of restorations bonded to enamel was greater than that of those bonded to dentin. The present study corroborates these findings since the teeth restored with occlusal veneers bonded to enamel achieved significantly higher fracture strength than the teeth restored with occlusal veneers bonded to dentin. Thus, the second hypothesis was accepted.

Group C (sound teeth) achieved higher fracture strength and did not differ significantly from Group 0.3E. A possible factor related to this finding is the wear of the dental structure that was less in enamel preparation in comparison with dentin preparation, preserving greater dental substrate. 
However, regardless of the substrate (enamel or dentin) or the restoration thickness ( 0.3 or $0.6 \mathrm{~mm}$ ), the fracture strength values were higher than the bite forces registered in patients. In forced bite tests, the value of $922 \mathrm{~N}$ was reached, and 1,120 N in patients with bruxisms (24). These are important data, showing that even with a $0.3-\mathrm{mm}$-thick veneer in the occlusal region; the restored teeth had a fracture strength similar to that of sound teeth.

Structural defects in ceramics and their absence of plastic deformation contribute to the strength of these materials (22). PICN restorations, such as Vita Enamic ${ }^{\oplus}$, are obtained by CAD/CAM technology. The ceramic blocks of PICN have a more homogeneous structure, with fewer defects (13). This is an important characteristic and must have a significant contribution to the high fracture strength values of the teeth restored with ultrathin occlusal veneers. The stresses are more effectively distributed in a more homogeneous material and promote strength against breakdown phenomena (13).

Most of the failures were classified as reparable. In this case, the tooth structure would not be lost, and a new restorative procedure could be performed. However, the interpretation of the results must include the limitations of a laboratory experiment that do not reproduce the complexity of the oral environment or the masticatory biomechanics. During the fracture strength test, a constant axial load was applied to the sample until fracture. It can be considered a limitation of the study since fractures by a constant axial load do not occur clinically (25). Despite this limitation, the results of this mechanical test allow a comparison of the fracture strengths among different restorative techniques and with sound teeth. Another limitation could be the small sample size of the study, even though it was possible to show significant differences in fracture strength between the substrates as well as between the different thicknesses of the occlusal veneers.

The results obtained in this study seem to provide good perspectives in relation to the clinical use of ultrathin occlusal veneers made of PICN in cases in which the remaining dental structure must be preserved or in cases in which there is limited interocclusal space due to the wear of the teeth. In addition, the dentists are advised to maintain as much enamel surface area as possible during tooth preparation, since the results of fracture strength are higher when the occlusal veneers were bonded to this substrate.

Considering the limitations of this study, it was possible to conclude that the teeth restored with 0.3-mm-thick occlusal veneers achieved higher fracture strength than the teeth restored with 0.6-mmthick occlusal veneers. The substrate influenced the fracture strength of the teeth restored with ultrathin occlusal veneers, which was higher when bonded to enamel.

\section{Acknowledgments}

This study was funding in part by the Coordination for the Improvement of Higher Education Personnel (CAPES, Brazil) - Finance Code 001.

\section{Resumo}

0 objetivo foi avaliar, in vitro, a resistência à fratura de dentes restaurados com facetas oclusais de Vita Enamic $^{\oplus}$ com 0,3 ou 0,6 mm de espessura e cimentadas em esmalte ou dentina. Cinquenta terceiros molares foram distribuídos em grupos $(n=10)$ : Grupo C-controle (dentes hígidos); Grupo 0,3E facetas oclusais com 0,3 mm de espessura cimentados em esmalte; Grupo 0,6E - facetas com 0,6 mm de espessura cimentados em esmalte; Grupo 0,3D - facetas com 0,3 mm de espessura cimentados em dentina; Grupo 0,6D - facetas com 0,6 mm de espessura cimentados em dentina. Após cimentação com Single Bond Universal Filtek Z-100, as amostras foram submetidas ao teste de resistência à fratura em máquina de ensaio universal. As falhas foram classificadas em reparáveis e irreparáveis. Os resultados foram analisados pelo teste ANOVA de duas vias e uma via $(\alpha=0,05)$ seguido do teste de Tukey. Os dentes restaurados com facetas oclusais com $0,3 \mathrm{~mm}$ de espessura $(2658 \mathrm{~N}$ ) obtiveram resistência à fratura estatisticamente superior aos dentes restaurados com facetas com 0,6 mm $(2070 \mathrm{~N})(p=0.017)$. Os dentes restaurados com facetas cimentadas em esmalte $(2648 \mathrm{~N})$ tiveram resistência à fratura estatisticamente maior comparada aos dentes restaurados com facetas cimentadas em dentina (2049 N) ( $p=0.015)$. Grupo C (3355 N) e Grupo 0,3E (2965 N) não diferiram estatisticamente entre si, tendo resistência à fratura estatisticamente superior aos outros grupos $(p<0.05)$. As fraturas foram predominantemente reparáveis. Os dentes restaurados com facetas oclusais com $0,3 \mathrm{~mm}$ de espessura apresentaram maior resistência à fratura comparada aos dentes restaurados com facetas com 0,6 $\mathrm{mm}$. 0 substrato influenciou a resistência à fratura dos dentes restaurados com facetas oclusais, sendo maior quando cimentadas ao esmalte. 


\section{References}

1. Bartlett D, Phillips K, Smith B. A difference in perspective - The North American and European interpretations of tooth wear. Int J Prosthodont 1999;12:401-408.

2. Al-Omiri MK, Lamey PJ, Clifford T. Impact of tooth wear on daily living. Int J Prothodont 2006;19:601-605.

3. Schlichting LH, Maia HP, Baratieri LN, Magne P. Novel-design ultra-thin CAD/CAM composite resin and ceramic occlusal veneers for the treatment of severe dental erosion. J Prosthet Dent $2011 ; 105: 217-226$.

4. Heck $K$, Paterno $H$, Lederer $A$, Litzenburger $F$, Hickel $R$, Kunzelmann KH. Fatigue resistance of ultrathin CAD/CAM ceramic and nanoceramic composite occlusal veneers. Dent Mater 2019;35:13701377.

5. Davidowitz G, Kotick PG. The use of CAD/CAM in dentistry. Dent Clin North Am 2011;55:559-570.

6. Andrade JP, Stona D, Bittencourt HR, Borges GA, Burnett LH Júnior, Spohr AM. Effect of different computer-aided design/computer-aided manufacturing (CAD/CAM) materials and thicknesses on the fracture resistance of occlusal veneers. Oper Dent 2018;43:539-548.

7. Dirxen $C$, Blunck U, Preisser S. Clinical performance of a new biomimetic double network material. Open Dent J 2013;6:118-122.

8. Ioannidis A, Mühlemann S, Özcan M, Hüsler J, Hämmerle CHF. Ultra-thin occlusal veneers bonded to enamel and made of ceramic or hybrid materials exhibit load-bearing capacities not different from conventional restorations. J Mech Behav Biomed Mater 2019;90:433-440.

9. Al-Akhali M, Kern M, Elsayed A, Samran A, Chaar MS. Influence of thermomechanical fatigue on the fracture strength of CAD-CAM-fabricated occlusal veneers. J Prosthet Dent 2019;121:644-650.

10. Maeder M, Pasica P, Enderb A, Özcanc M, Benicc Gl, loannidisc A. Load-bearing capacities of ultra-thin occlusal veneers bonded to dentin. J Mech Behav Biomed Mater. 2019 Jul;95:165-171.

11. Al-Akhali M, Chaar MS, Elsayed A, Samran A, Kern M. Fracture resistance of ceramic and polymer-based occlusal veneer restorations. J Mech Behav Biomed Mater 2017;74:245-250.

12. Yu H, Zhao Y, Li J, Luo T, Gao J, Liu H, Liu W, Liu F, Zhao K, Liu F, Ma C, Setz JM, Liang S, Fan L, Gao S, Zhu Z, Shen J, Wang J, Zhu Z, Zhou X. Minimal invasive microscopic tooth preparation in esthetic restoration: a specialist consensus. Int J Oral Sci 2019; 11:31.

13. Mainjot AK, Dupont NM, Oudkerk JC, Dewael TY, Sadoun MJ. From artisanal to CAD-CAM blocks: State of the art of indirect composites. J Dent Res 2016;95:487-495.

14. Facenda JC, Borba $M$, Benetti $P$, Della Bona $A$, Corazza PH. Effect of supporting substrate on the failure behavior of a polymer-infiltrated ceramic network material. J Prosthet Dent 2019;121:929-934.

15. Coldea A, Swain MV, Thiel N. Mechanical properties of polymer-infiltrated-ceramic-network materials. Dent Mater 2013;29:419-426.

16. Spohr AM, Sobrinho LC, Consani S, Sinhoreto MAC, Knowles JC. Influence of surface conditions and silane agent on the bond of resin to IPS Empress 2 ceramic. Int J Prosthodont 2003;16:277-282.

17. Moro AFV, Ramos AB, Rocha GM, Perez CDR. Effect of prior silane application on the bond strength of a universal adhesive to a lithium disilicate ceramic. J Prosthet Dent. 2017; 118:666-671.

18. Lopes LCP, Terada RSS, Tsuzuki FM, Giannini M, Hirata R. Heating and preheating of dental restorative materials - a systematic review. Clin Oral Investig 2020; 24:4225-35.

19. Oh S, Shin SM, Kim HJ, Paek J, Kim SJ, Yoon TH, Kim SY. Influence of glass-based dental ceramic type and thickness with identical shade on the light transmittance and the degree of conversion of resin cement. Int J Oral Sci. 2018; 10:1-5.

20. Attia A, Abdelaziz KM, Freitag $S$, Kern M. Fracture load of composite resin and feldspathic all ceramic CAD/CAM crowns. J Prosthet Dent 2006; 95:117-123.

21. de Kok P, Kleverlaan $C J$, Jageer $N$, Kuijs $R$, Feilzer A. Mechanical performance of implantsupported posterior crowns. J Prosthet Dent 2015; 114:59-66.

22. Craig RG, Powers JM. Restorative Dental Materials. São Paulo: Santos; 2004

23. Piemjai $M$, Arksornnukit M. Compressive fracture resistance of porcelain laminates bonded to enamel or dentin with four adhesive systems. J Prosthodont 2007;16:457-464.

24. Sakaguchi RL, Douglas WH, Delong R, Pintado MR. The wear of a posterior composite in an artificial mouth: a clinical correlation. Dent Mater 1986;2:235-240. 
25. Shirakura $A$, Lee $H$, Geminiani $A$, Ercoli $C$, Feng $C$. The influence of veneering porcelain thickness of all-ceramic and metal ceramic crowns on failure resistance after cyclic loading. J Prosthet Dent 2009;101:119-127.

Received: $27 / 05 / 2021$

Accepted: 24/09/2021 